\title{
The relevance of apoptosis for cellular homeostasis and tumorigenesis in the intestine
}

\author{
Andrew G Renehan FRCS FDS, Simon P Bach FRCS, Christopher S Potten PhD DSc
}

AG Renehan, SP Bach, CS Potten. The relevance of apoptosis for cellular homeostasis and tumorigenesis in the intestine. Can J Gastroenterol 2001;15(3):166-176. Intestinal epithelium is a rapidly renewing tissue in which cell homeostasis is regulated by a balance among proliferation, growth arrest, differentiation and apoptosis (programmed cell death). Until recently, studies on oncogenesis have focused on the regulation of cell proliferation. The recognition that apoptosis must be understood to comprehend how appropriate cell numbers are maintained and how alterations in any part of the equation can contribute to malignancy has led to an explosion of research in this field. The first half of this review gives an overview of morphology and mechanisms of apoptosis, emphasizing key areas of genetic control such as the $b c l-2$ family and $p 53$. The second half of the review focuses on the role of apoptosis in normal cellular homeostasis and tumorigenesis in the gastrointestinal epithelium. The importance of understanding the molecular biology of apoptotic pathways in cancer therapy and future directions are also addressed.

Key Words: Apoptosis; bcl-2 family; Gastrointestinal cancer; Intestinal crypt; $\mathrm{p} 53$; Stem cell

\section{Rôle de l'apoptose dans l'homéostasie cellu- laire et la tumorogenèse dans l'intestin}

RÉSUMÉ : L'épithélium intestinal est un tissu qui se renouvelle rapidement et dans lequel l'homéostasie cellulaire est régulée par un équilibre entre la prolifération, l'arrêt de croissance, la différenciation et l'apoptose (mort cellulaire programmée). Jusqu'à tout récemment, les études sur l'oncogenèse ont été centrées sur la régulation de la prolifération cellulaire. La reconnaissance que l'apoptose doit être mieux comprise si l'on veut déterminer comment les cellules sont maintenues en nombre approprié et comment le changement de toute partie de l'équation peut contribuer à la malignité a mené à une explosion de recherches dans ce domaine. La première moitié de la présente étude donne une vue d'ensemble de la morphologie et des mécanismes de l'apoptose, en mettant l'accent sur les aspects clés de la lutte génétique, par exemple la famille bcl-2 et p53. La deuxième partie porte sur le rôle de l'apoptose dans l'homéostasie cellulaire normale et la tumorogenèse dans l'épithélium gastro-intestinal. Il est également question de la nécessité de comprendre la biologie moléculaire des voies de l'apoptose dans le traitement des cancers ainsi que des orientations futures.

This mini-review was prepared from a presentation made at the World Congress of Gastroenterology, Vienna, Austria, November 6 to 11, 1998 CRC Department of Epithelial Biology, Paterson Institute for Cancer Research, Christie Hospital NHS Trust, Manchester, United Kingdom Correspondence and reprints: Professor CS Potten, Epistem Ltd, Incubator Building, Grafton Street, Manchester M13 9XX, United Kingdom.

E-mail cpotten@picr.man.ac.uk

Received for publication September 13, 1999. Accepted September 27, 1999 
A poptosis is an active, energy-dependent process of cell death that occurs during development in response to certain physiological stimuli and also, in steady-state synthesis, in response to cell injury and stress (1). (The term 'apoptosis' is derived from the Greek words describing the dropping off and falling off of pellets from flowers or leaves from trees [2].) This type of cell death involves the deletion of discrete cells within a tissue and differs from necrotic cell death in that the cells that are eliminated by apoptosis are processed without the initiation of an inflammatory response.

The role of apoptosis in tumorigenesis is now well established (reviewed in 3-8). Furthermore, there is increasing recognition that many of the effects of chemo- and radiotherapeutic agents are mediated by apoptosis (reviewed in 2,9-11). The first half of this review gives an overview of the morphology and mechanisms of apoptosis, emphasizing key areas of genetic control, such as the bcl-2 family and p53. The second half of the review focuses on the role of apoptosis in normal homeostasis and tumorigenesis in the gastrointestinal epithelium. The importance of understanding the molecular biology of apoptotic pathways in cancer therapy and future directions are also addressed. Discussion is restricted to the simple epithelium of the hollow organs of the gastrointestinal tract rather than the liver and pancreas.

\section{MORPHOLOGY AND DETECTION OF APOPTOSIS}

Morphological features of apoptosis: The seminal work of Kerr et al (2) in 1972, building on earlier observations in vertebrates (12) and insects (13), should be read by those interested in assaying apoptosis because of the excellent photomicrographs that document the morphological features of the process.

The morphological features of apoptosis can be separated, for clarity, into three sequential phases (14). Initially, a cell loses contact with its neighbours and detaches from its substratum; the chromatin becomes condensed into crescent-like caps at the nuclear periphery. There is nucleolar disintegration, compaction of organelles with endoplasmic reticulum dilation, clumping of ribosomal particles, cytoskeletal filament aggregation and cytoplasmic volume reduction. There is also loss of specialized surface structures such as microvilli and junctional structures. In the second phase, blebs of plasma membrane develop, which can split away from the cells. This is a very dramatic process and can give the cells a 'boiling' appearance when viewed on timelapse video microscopy. Both the nucleus and the cytoplasm split into fragments of various sizes, with the remaining cell becoming a round, smooth membrane-bound body referred to as an 'apoptotic body'. In the third phase, there is progressive degeneration of the residual nuclear material and cytoplasmic structures. At this stage, the plasma membrane becomes permeable to dyes such as tryptan blue. Apoptosis is rapid and is often completed in vivo in 4 to $8 \mathrm{~h}$, but it may be much quicker in embryogenic cell systems and in some cell cultures.

\section{TABLE 1}

\section{Techniques for the detection of apoptosis}

\begin{tabular}{l}
\hline Traditional microscopy (11) \\
Light microscopy \\
Electron microscopy \\
Acridine orange fluorescence \\
Biochemical approaches (121) \\
Agarose gel electrophoresis \\
Pulsed field electrophoresis \\
Flow cytometry (reviewed in 122) \\
Unfixed cells (123) \\
Fixed cells (eg, propidium iodide [124]) \\
In situ detection of broken DNA strands \\
5'-triphosphate nick end-labelling (TUNEL) (15) \\
In situ end-labelling (ISEL) (16) \\
Recently established techniques \\
Annexin V immunohistochemical expression (125) \\
Clusterin immunohistochemical expression (126) \\
In situ hybridization using digoxigenin-labelled poly (A) \\
oligonucleotide probes (127)
\end{tabular}

References appear in parentheses

Identification and quantification of apoptosis: The number of techniques available for identifying apoptosis are summarized in Table 1. Because apoptosis is defined by a series of distinct changes in cellular morphology, light and electron microscopy provide the best evidence for detecting and quantifying apoptosis in intestinal epithelium. Many contemporary studies on intestinal apoptosis supplement traditional microscopy with in situ techniques for the detection of broken DNA strands $(15,16)$. In the strictest sense, 'programmed cell death' may be applied to circumstances where death is initiated by a genetic program that leads to autonomous cell destruction. It is now recognized that a cell may undergo 'programmed cell destruction' without fulfilling some, or all, of the morphological criteria of apoptosis (17). When considering apoptosis in the intestinal epithelium, this is not just a matter of semantic debate. For example, epithelial cells are shed from the tips of the intestinal villi. Because the dimensions of the villi tips are remarkably constant, it seems reasonable to assume that the shed cells are undergoing a form of programmed cell death. However, cells complying with the strict morphological definition of apoptosis are rarely seen at the tip of the intestinal villus, raising the question of whether other mechanisms account for cell shedding.

When quantifying apoptosis by morphological features, other caveats to the technique should be borne in mind $(18,19)$. The rapid nature of apoptosis means that in any static analysis, a very small number of apoptotic cells observed at a given instant might, in fact, reflect a very considerable contribution to cell turnover. There are recognized variations in the speed of apoptosis among cell types and in relation to different insults. For example, the halflife of apoptotic fragments following treatment with hydroxyurea is approximately $3.5 \mathrm{~h}$, while following radia- 


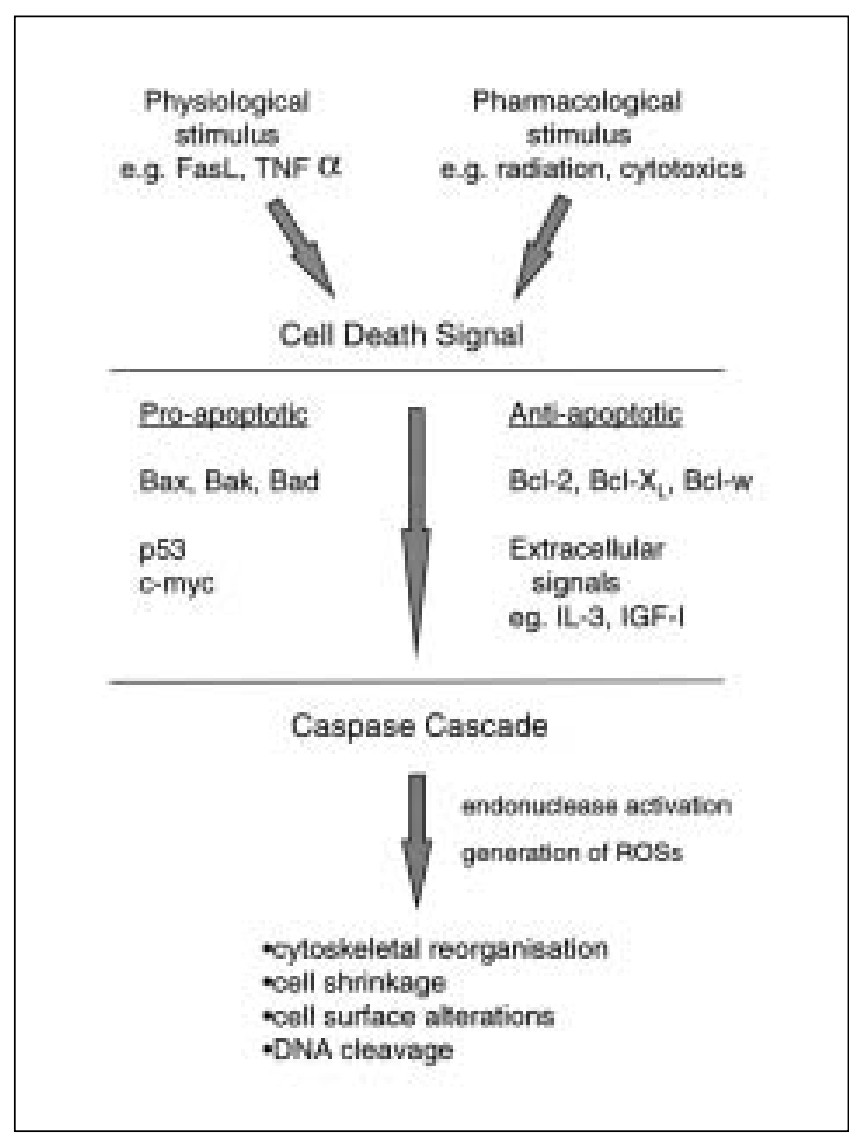

Figure 1) An overview of apoptotic mechanisms. The schematic diagram illustrates apoptosis initiation, signal transduction, genetic regulation and effector mechanisms. FasL Fas ligand; IGF Insulin-like growth factor; IL Interleukin; ROS Reactive oxygen species; TNF $\alpha$ Tumour necrosis factor alpha

tion it is $15 \mathrm{~h}$ (data from our laboratory). A caveat to these remarks is that such half-life measurements relate to the removal of apoptotic bodies by phagocytic digestion and cell migration combined with the true duration of the cell death process. Hall and Coates (20) have described a counting technique termed the 'wandering mean method' in an attempt to overcome some of these limitations.

\section{MECHANISMS OF APOPTOSIS}

In its simplest model, the stages of apoptosis can be considered as initiation and signal transduction, genetic regulation (discussed in detail below) and effector mechanisms (Figure 1). There are numerous stimuli of apoptosis acting through a variety of pathways, some of which are as yet poorly defined. Broadly speaking, there are five pathway classes:

- receptor-mediated stimuli, such as glucocorticoids, interleukin (IL)-3 withdrawal and activation of tumour necrosis factor receptor or 'death receptor' family (Fas/CD95/APO-1 and tumour necrosis factor-R1) (reviewed in 21);

- stress signals through the sphingomyelin pathway, including ceramide and c-Jun kinase (reviewed in 22);

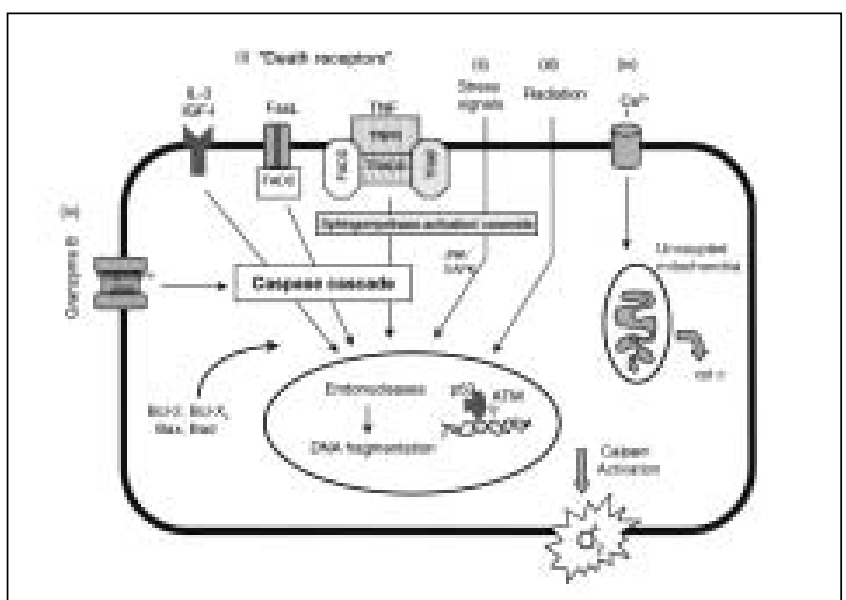

Figure 2) Schematic diagram illustrating the various pathways of apoptosis resulting in endonuclease cleavage of DNA and regeneration of reactive oxygen species (explained in text). Multiple apoptotic signals converge on caspase activation, many of which are regulated by Bcl-2 family proteins. ATM Ataxia-telangectasia malignancies gene; cyt c Cytochrome c; FADD Fas-associated death domain protein; FasL Fas Ligand; IGF-I Insulin-like growth factor-1; IL-3 Interleukin-3; JNK/SAPK c-Jun kinase/stress-activated protein kinase; TNF Tumour necrosis factor; TNFR Tumour necrosis factor receptor; TRADD TNFRassociated death domain protein; TRAF TNFR-associated factor

- those that induce DNA damage such as $\mathrm{x}$-rays and other forms of ionizing and nonionizing radiation, including $p 53$ pathways;

- poorly understood pathways such as uncoupling of mitochondria via calcium channels and direct activation of caspase via granzyme B; and

- agents that cause direct physical damage such as heat, cold and ultraviolet light (Figure 2).

The search to understand the downstream effector pathways of apoptosis led to the identification of a whole family of cellular proteases termed 'caspases' (cysteine proteases that cleave after aspartate residues) (reviewed in 23,24). There are at least 13 different types that may be activated in response to different apoptotic signals. Additionally, the distribution of caspase isotypes varies between cells and tissues, and it is likely that different activation systems operate at different sites. The 'classical pathway' includes Bcl-2 family proteins, Apaf-1 (apoptosis proteases-activating factor) and caspase 9 (25). An alternative pathway is ligandinduced aggregation of 'death receptors', leading to activation of caspase 8 via the adapter protein Fas-associated death domain protein (FADD)/Mort1 (reviewed in 26). The precise mechanisms leading to cell death after activation of caspases are generally unclear, although cleavage of DNA by endonuclease is a cardinal feature (27).

GENETIC REGULATION OF APOPTOSIS Caenorhabditis elegans and apoptosis: Observations made in the nematode Caenorhabditis elegans have laid the foundation for understanding the genetic organization of the 
TABLE 2

\section{Regulatory proteins of apoptosis}

\begin{tabular}{|c|c|}
\hline Anti-apoptotic (pro-survival) & Pro-apoptotic \\
\hline \multicolumn{2}{|l|}{ Bcl-2 family } \\
\hline Bcl-2, Bcl-x, Mcl-1, & Bak subfamily: \\
\hline \multirow[t]{3}{*}{ Bcl-w (128), } & Bax, Bak, Bok, Bcl-xs \\
\hline & BH-3 only homologues: \\
\hline & Bid, Bad, Bik, Blk, Hrk, Bim \\
\hline \multicolumn{2}{|l|}{ Others } \\
\hline RB & p53 family: p53, p73 (59) \\
\hline Survivin (129) & c-jun (27) \\
\hline Bcl-10 (130) & c-myc (131) \\
\hline Bag-1 (132) & \\
\hline
\end{tabular}

References appear in parentheses

control of mammalian cell death (reviewed in 28,29). During this organism's development, precisely 131 of 1090 somatic cells undergo programmed cell death (30). Eleven genes control this process, of which three, called ced-9, ced-3 and ced-4 (the C elegans 'apoptosome'), have been studied in detail. Normal functioning of ced-9, which has striking similarity to the mammalian $b c l-2$ gene, is required to prevent cell death (31). Moreover, human bcl-2 can prevent cell death in $\mathrm{C}$ elegans and can substitute for ced-9 in ced-9-deficient nematodes. The ced-3 gene encodes a $2.8 \mathrm{~kb}$ mRNA, which has significant homology with the human caspase $(32,33)$. Part of the sequence of Apaf-1 shows striking similarity to that of ced-4, while Apaf-2 is homologous to cytochrome c (34).

Mammalian Bcl-2 family genes: The $b c l-2$ oncogene was initially discovered as a result of its involvement in the chromosomal translocation $\mathrm{t}(14 ; 18)(\mathrm{q} 32 ; \mathrm{q} 21)$ in human Bcell lymphoma (35). Subsequently, it was demonstrated that $b c l-2$ prevented the induction of apoptosis in B cells following withdrawal of IL-3 (36). This anti-apoptotic property of bcl-2 has been demonstrated in many cell systems (reviewed in 37,38). The Bcl-2 protein has a molecular mass of $24 \mathrm{kDa}$ and has been shown to be located in the nuclear membrane, mitochondrial membranes and endoplasmic reticulum (39). Its mechanism of action is not understood, although particular attention has been paid to the possibility that its anti-apoptotic effect is via an antioxidant action (40).

It has become clear that Bcl-2 is only one of a family of related proteins that are involved in apoptosis control (Table 2). These all have a degree of homology with Bcl-2, especially within the conserved domains $\mathrm{BH} 1$ and $\mathrm{BH} 2$. A third domain, $\mathrm{BH} 3$, appears to confer pro-apoptotic activity (41). Bcl-x is one family member that can be alternatively spliced to form either Bcl- $\mathrm{x}_{\mathrm{L}}$ (which inhibits cell death) or Bcl- $x_{S}$ (which promotes apoptosis) (42). Bcl-x protein expression has been demonstrated in a number of tissues, but the distribution is different from that of Bcl-2 (43). Bax (bcl-2-associated $\mathrm{x}$ protein) encodes a $21 \mathrm{kDa}$ protein that can either homodimerize or heterodimerize with Bcl-2 (44), and it is proposed that the $\mathrm{Bcl}-2$ :Bax ratio determines whether a cell will undergo apoptosis or survival - Bcl-2 in excess protects cells from apoptosis, and Bax in excess (homodimers predominate) induces cell apoptosis. This is known as the Bcl-2/Bax 'rheostat'. Bad and Bak are additional Bcl-2 family pro-apoptotic members that can either homodimerize or heterodimerize with Bcl-2 $(45,46)$. It is likely that these proteins interact with one another and other proteins to different degrees in different cell types to control apoptosis.

The $p 53$ tumour suppressor gene: The p53 cellular protein was first described by Lane and Crawford (47), and Linzer and Levine (48) as a complex with the simian virus 40 large $T$ antigen in virally transformed rodent cells. Mutant p53 acts as an oncogene, but wild p53 is a tumour suppressor gene because transfection into cells suppresses transformation caused by other oncogenes. The gene is located on chromosome $17 \mathrm{p}$ in humans, and mutations of p53 have been found in a wide range of human cancers, including most gastrointestinal malignancies, although the site of mutations depends on tumour type (49-51).

The biochemical function of $p 53$ is to bind to specific DNA sequences, including the promoters of the $m d m-2$ (murine double minute), Gadd-45 (growth arrest and DNA damage) and Waf-1/Cip-1 (Cdk-interacting protein) genes. The last of these is probably the most important; the gene product of Waf-1/Cip-1 is a $21 \mathrm{kDa}$ protein $\left(\mathrm{p} 21^{\mathrm{WAF} 1 / \mathrm{CIP} 1}\right)$ that can bind to cyclin A- and E-dependent kinase II and cyclin $\mathrm{D}$-dependent kinase, preventing progression past the G1 phase of the cell cycle, and may also be involved in controlling G2 progression in some cell types (reviewed in 52).

In 1992, Lane (53) proposed that p53 was the "guardian of the genome". If DNA is damaged, $p 53$ accumulates and switches off replication to arrest cells in G1 and to allow extra time for repair. If repair fails, $p 53$ may trigger cell suicide by apoptosis. The importance of this is illustrated by experiments demonstrating that p53 wild-type mouse embryos, but not $p 53$ null mice embryos, will readily abort following radiation-induced teratogenesis $(54,55)$. How $p 53$ induces apoptosis is not clear, and there may be more than one mechanism - p53 alters the balance between Bax and $\mathrm{Bcl}-2$, favouring cell death (56); alternatively, p53 increases the expression of at least 14 genes, termed "p53-induced genes', of which three are potent generators of reactive oxygen species (57). Whether a cell undergoes $p 53$-mediated growth arrest or $p 53$-mediated apoptosis is probably related to functional levels of p53 (52) and p21 WAF-1/CIP1 (58).

There is emerging evidence that, analogous to $b c l-2$, a p53 family of genes is involved in cell cycle control and apoptosis. Two additional members, p51 and p73, have recently been identified (reviewed in 59). Both proteins, at least when overproduced, can mimic the ability of p53 to induce apoptosis but, in contrast, appear infrequently mutated in human cancers.

Other apoptosis regulatory genes: Recently, an increasing number of transcription activators have been identified in the initiation and manifestation of apoptosis (reviewed in $60)$. Examples of cell growth inhibitory transcription fac- 
(a)

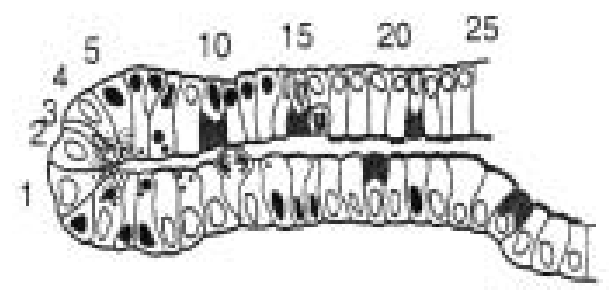

(b)

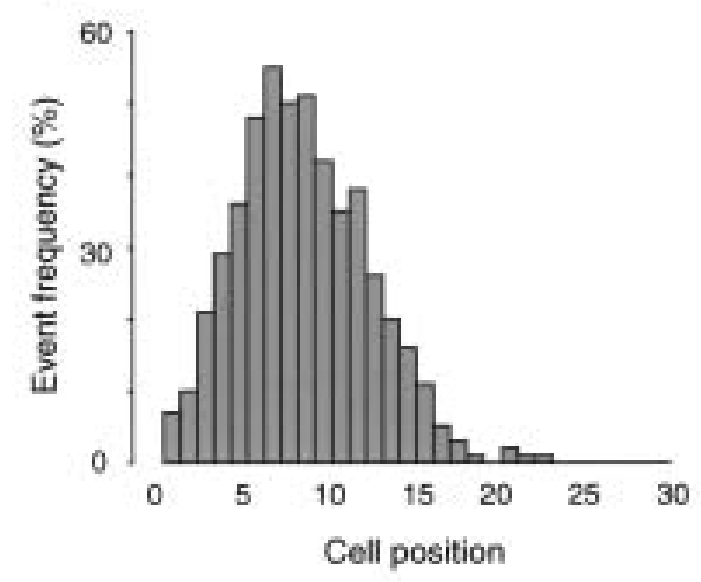

Figure 3) Evaluation of event frequency by cell position. a A longitudinal section of a colonic intestinal crypt, illustrating how the position of events up the crypt axis can be determined (position 1 being at the crypt base). $\mathrm{b}$ When a number of crypt cross-sections are counted, an event frequency at each cell position can be plotted

tors are insulin receptor substrate-1, signal transduction and activation of transcription (STAT) proteins, and examples of cell growth stimulatory transcription factors are c-myc, AP-1 and nur77.

\section{APOPTOSIS IN THE NORMAL INTESTINE}

Intestinal epithelium: The intestinal epithelium is a rapidly renewing tissue in which tissue homeostasis depends on both cell proliferation and cell death (reviewed in 61). Most studies of this renewal process have focused on the control of cell proliferation. However, it is becoming increasingly apparent that the control of cell death is equally if not more important in the regulation of cell numbers and ultimately susceptibility to neoplastic transformation.

Potten and co-workers (reviewed in 62-65) have developed and validated a method for quantifying epithelial cells in relation to their position along the long axis of the intestinal crypt, with position 1 at the base of the crypt (Figure 3). Using this methodology, it is clear that the intestinal crypt has a well defined and polarized topographical organization in which the hierarchy, lineage or cellular 'age' can be assessed by the position of that cell in the tissue. Careful analysis of cell positional behaviour and hierarchies in the crypts of the murine colon and small intestine suggests that the cell renewal in colonic and small intestinal crypts is broadly similar, with a few important differences. In the murine small intestine, there are approximately six stem cells or lineage ancestor cells per crypt located at cell positions 4 to 5 , just above the Paneth cells. In the murine colon, the number of stem cells is probably similar, but they are thought to be located at the base of the colonic crypts (cell positions 1 to 2) (66).

Spontaneous and induced apoptosis: When studying apoptosis and using the murine model, intestinal tissue is fixed in Carnoy's fixative, carefully sectioned so that the crypt/ villus units can be viewed in longitudinal section and stained with hematoxylin and eosin. Apoptotic bodies and fragments can be readily identified and reliably distinguished from mitotic and normal cells. To quantify apoptosis, each cell position along the long axis of the crypt, counting the base of the crypt as cell position 1, is scored as to whether it contains a normal cell, an apoptotic body or fragment, or a cell undergoing mitosis. These data relating cell status to cell position can be simply analyzed by computer (67). An apoptotic index defined as the total number of cells with one or more apoptotic fragments at that cell position can be calculated. Statistically valid results can be obtained by counting 200 to 300 well orientated half crypt sections from four to six mice (68). Over a decade of performing studies at our laboratory, we have shown that the pattern of spontaneous apoptosis in the small intestine is different from that in the large intestine. In the former, spontaneous apoptotic cells are readily observed but are restricted to the stem cell region (positions 4 to 5), whereas in colonic crypts, spontaneous apoptosis is very infrequent. Some authors report that spontaneous apoptosis occurs predominantly in the outer third compartment of the colonic intestinal crypt $(69,70)$, and others indicate that it occurs within the lower crypt compartments (71); we have observed it occurring in a less topologically restricted way (Figure 4). Critically, however, few apoptotic cells are observed at the base of the colonic crypts, where the stem cells are located. This naturally occurring or spontaneous apoptosis, which is p53-independent, has been interpreted as part of the stem cell homeostatic mechanism. When the process is regressed by bcl-2, the colonic stem cell numbers, and hence carcinogen target cells, may gradually drift upwards with time (63). Additionally, in comparison with the small intestine, the damage-induced apoptosis response in the large intestine is blunted and distributed throughout the crypt. These observations of the differential amounts and position of apoptosis in the crypts led to the hypothesis that damaged small intestinal stem cells were deleted by an 'altruistic' apoptotic process, thereby protecting this site from genetic and carcinogenic damage, whereas in the colon, damaged cells survive with the consequence of increased susceptibility to neoplastic transformation (62).

Investigations of apoptosis at other sites in the gastrointestinal tract are less plentiful. Hall et al (71) found morphological evidence of apoptosis, both at the base of gastric 


\section{(a) small intestine}

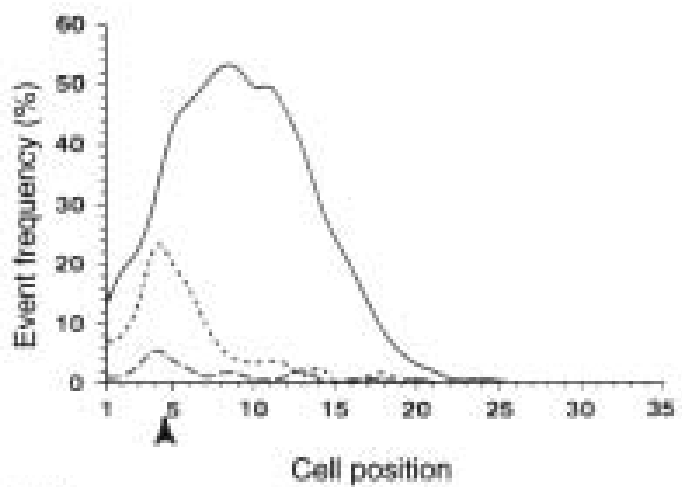

(b) colon

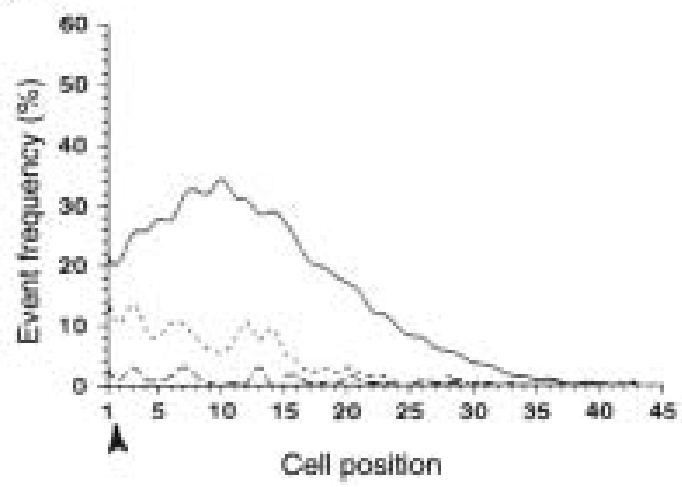

Figure 4) Frequency of S-phase and apoptotic cells along the length of an intestinal crypt. a Small intestine. b Colon. The frequency of cells labelled with tritiated thymidine (S-phase) at each cell position (unirradiated adult mouse) is shown as a continuous line; the frequency of spontaneously occurring apoptosis (unirradiated adult mouse) is shown as a dashed line; and frequency of radiation-induced apoptosis ( $42 \mathrm{~h}$ after 1 Gy gamma-irradiation) is shown as a dotted line. In the small intestine, peak frequency of apoptosis is at cell positions 4 to 6 . In contrast, apoptosis is less topographically restricted in the colon. The proposed stem cell positions for small intestine and colon are indicated by the arrowheads

glands and at the luminal surface, while other studies have reported evidence of apoptosis along the entire length of the gastric mucosal pit (72). Helicobacter pylori, the principle cause of type B gastritis and peptic ulcer disease, and classified as a type I carcinogen for gastric cancer (73), regulates gastric cell growth by direct induction of apoptosis. In terms of tumorigenesis, this is paradoxical (see below), but one explanation may be that long term increases in apoptotic rates act as a stimulus to hyperproliferation and the subsequent promotion of neoplasia $(74,75)$.

Bcl-2 family, $\mathrm{p} 53$ and apoptosis in the intestinal crypt: $\mathrm{Bcl}-2$ is minimally expressed in the small intestine of both mouse and human but more strongly expressed at the base of colonic crypts in both species, indicating that this may be involved in over-riding the apoptotic (both spontaneous and induced) homeostatic mechanisms in these cells. This hypothesis is supported by the finding that, in $b c l-2$ knockout mice, the incidence of spontaneous and induced apop-

\section{(a) small intestine}

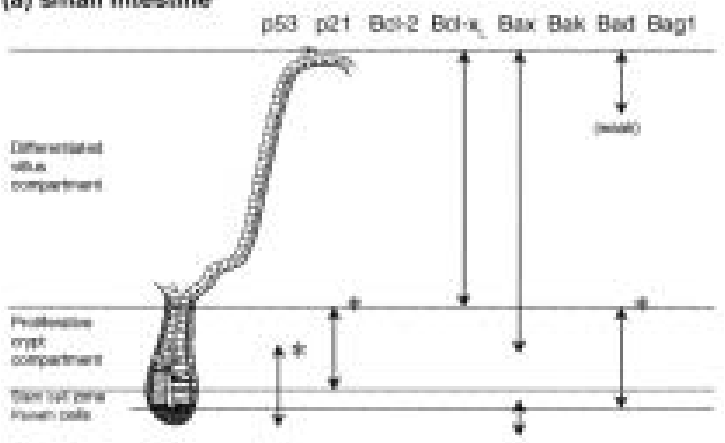

(b) colon

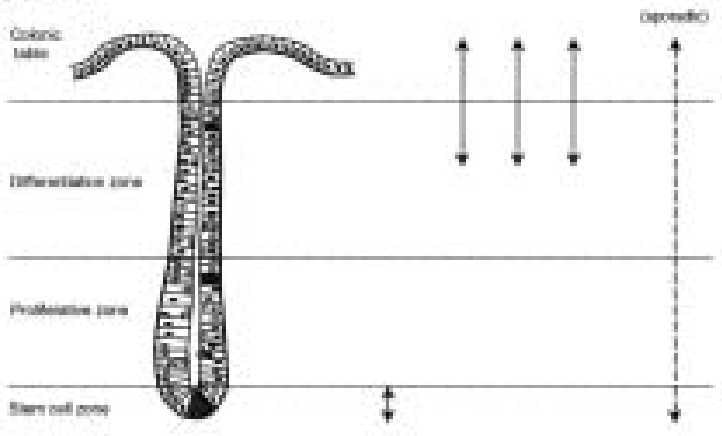

Figure 5) Diagram of expression of p53, p21 and various members of the Bcl-2 family in the small intestinal (a) and colonic epithelia (b). *Radiation induced

tosis is dramatically increased in the stem cell region of the colon but unchanged in the stem cell region of the small intestine (76).

Immunohistochemical and immunoblot studies from Krajewski et al (77-79), Kitada et al (80), and Wilson and Potten (81) have characterized the intestinal expression of various Bcl-2 family members (Figure 5). Moss et al (69), observing apoptosis mainly at the luminal surface in normal human colonic epithelium, reported a strong positional correlation between Bak expression and apoptosis. Overall, the differential positional expression of pro- and anti-apoptotic factors fits with the hypothesis that their ratios in a given cell ('rheostats') are important in controlling the sensitivity of that cell to apoptosis.

The expression of wild-type $\mathrm{p} 53$ in the normal intestinal epithelium is low; therefore, the role of $\mathrm{p} 53$ in spontaneous apoptosis was examined in studies comparing normal and p53-knockout mice. Interestingly, the levels of spontaneous apoptosis were similar in both types of mice, indicating that spontaneous apoptosis is p53-independent (68). In contrast, when the changes that occur in p53 expression following exposure to ionizing radiation in the small and large bowel were examined, interesting patterns emerged. In the small intestine, there was a strong p53 immunoreactivity that overlaid the apoptosis cell position incidence frequency plot precisely, whereas radiation damage in the large intestine resulted in increased levels of p53 and apoptosis 
occurring at a lower level and distributed along the whole crypt. However, apoptotic bodies were surprisingly negative for $\mathrm{p} 53$ protein expression, suggesting that the presence of p53 at cell position 4 (stem cells) is associated with regulation of cell cycle check point genes and/or initiation of repair mechanisms (82). The p53 knockout studies suggested that damage-induced apoptosis is p53-dependent in the small intestine and illustrates the limited ability of colonic stem cells to undergo apoptosis (83).

\section{APOPTOSIS AND INTESTINAL TUMORIGENESIS}

Animal models and cancer development: Over the past decade, the experimental use of transgenic models has helped elucidate some of the mechanisms underlying the pivotal role of apoptosis in oncogenesis (reviewed in 84). Transgenic mice bearing a bcl-2-immunoglobulin minigene designed to mimic the human $\mathrm{t}(14: 18)$ translocation highly express $b c l-2$ in B cells. As with the human B-cell lymphoma counterpart, lymphoid tissue from these mice progresses spontaneously to a benign hyperplasia and, after many years, to high grade malignant large B-cell lymphoma. The extended latency indicates that bcl-2 expression alone is insufficient for tumorigenesis and an additional transforming event, such as a rearranged myc gene, is required (85).

Additional studies using viral oncoproteins as tools in transgenic mice models have clearly shown a role for apoptosis suppression in tumour progression. Symonds et al (86) used a choroid plexus epithelium (CPE) model - a normally nondividing brain epithelium cell. Expression of a wild $\mathrm{T}$ antigen in CPE results in aggressive nonclonal tumour growth, whereas truncated $\mathrm{T}$ antigen $\left(\mathrm{T}_{121}\right)$, which inactivates the $\mathrm{pRB}$ (retinoblastoma) protein but not $\mathrm{p} 53$, induces very slow growing tumours (87). This indicates that p53 inactivation in these cells contributes to tumour progression rather than initiation. Indeed, tumour growth is retarded by wild-type p53 (88).

Apoptosis in intestinal tumorigenesis: What is the evidence that abnormalities in apoptosis are involved in the development of intestinal tumours? Using morphology to quantify apoptosis, a number of studies have found an increased apoptosis index from normal colonic epithelium through adenomas to the carcinoma stage $(89,90)$. Additional evidence comes from the observation that a number of dietary factors (eg, fibre) and chemopreventive agents (eg, nonsteroidal anti-inflammatory drugs ([NSAIDs]) prevent colonic tumour formation by promoting apoptosis. For example, it has been proposed that the chemopreventive effect of NSAIDs results from increased intestinal apoptosis brought about by decreased expression of $\mathrm{Bcl}-2$ as a result of cyclo-oxygenase (COX)-2 inhibition (91).

A further role of apoptosis in intestinal tumorigenesis may lie at the epithelial-lymphoid cell interface. Fas ligand (FasL) induces apoptosis in sensitive immunocytes (Fas receptor [FasR]/APO-1/CD95 receptor positive) and regulates several immune responses, including contributing to immune privilege. FasL was originally thought to be expressed only in lymphoid cells but has now been shown to be expressed in epithelial cells from many organs. This has been termed the 'Fas counter-attack' (92). FasL expression has been demonstrated in a number of human colon cancer cell lines in vitro (93) and neoplastic colon epithelial cells in vivo (94), suggesting that the Fas counter-attack is a prevalent mechanism of immune evasion in colonic cancers.

Bcl-2 family and p53 expression in intestinal tumours: Many groups have performed (mostly by immunohistochemical means) studies of $\mathrm{p} 53$ and Bcl-2 expression in colorectal neoplasia. Accepting the methodological limitations of these approaches (95), a number of general conclusions emerge that suggest that dysregulation of the expression of these apoptosis-controlling genes occurs during colorectal tumorigenesis:

- p53 protein expression occurs more frequently in colorectal carcinomas than in adenomas $(96,97)$ and is associated with a poorer prognosis (98). In sporadic colorectal carcinogenesis, $p 53$ mutations are likely to be a late event - a hypothesis supported by the observation that $\mathrm{p} 53$-null mice do not develop spontaneous colonic tumours (99) and mice with multiple intestinal neoplasia (MIN) mice (which carry a mutation in the adenomatous polyposis coli gene) do not show a change in the spectrum of intestinal tumours when rendered homozygously null for p53 (100).

- Within the conventional adenoma-carcinoma model, adenomas have generally been found to express more Bcl-2 than carcinomas $(98,101-104)$. Watson et al (104) showed that there was reciprocity of expression of Bcl-2 and p53 in some neoplasms that were dually stained for both proteins. This study also demonstrated higher levels of Bcl-2 expression in normal colonic crypts adjacent to carcinomas than in normal crypts more than $5 \mathrm{~cm}$ from the tumour, suggesting that changes in Bcl-2 expression occur at an early stage of colorectal tumorigenesis.

- A number of studies have shown that Bcl-2 expression is positively associated with a favourable clinical prognosis, although some data are conflicting $(98,105)$. The finding that colorectal carcinomas that have increased Bcl-2 expression (and consequently, one would suppose less apoptosis) had an improved prognosis is counterintuitive. Although this finding agrees with findings in breast cancer (106) and nonsmall cell lung cancer (107), it contrasts with findings in other tumours such as lymphoma (108), in which Bcl-2 confers a poorer prognosis. The explanation for this paradox is not fully established, but the finding that colonic adenomas, in general, express more Bcl-2 than adenocarcinomas suggests that carcinomas expressing Bcl-2 are developmentally 'earlier', stage for stage, and hence have a better prognosis. 
- One study has shown markedly elevated levels of Bcl- $\mathrm{x}_{\mathrm{L}}$ in colonic adenocarcinomas compared with normal intestinal mucosa (109). The study also showed normal expression of the pro-apoptotic protein Bak in adenomas but reduced expression in carcinomas, suggesting that reductions in Bak expression occur early in colorectal tumour progression. Bax expression (pro-apoptotic) was not significantly altered in either adenomas or carcinomas. It has recently been shown that the anti-apoptotic protein $\mathrm{Bcl}-\mathrm{w}$ is frequently expressed in colorectal adenomas, and particularly in adenocarcinomas, but absent in other carcinomas such as breast, stomach and cervix (110).

\section{THERAPEUTIC MANIPULATION OF APOPTOSIS IN COLORECTAL CANCER}

Chemotherapy and radiotherapy: Recent work has demonstrated that virtually all cytotoxic drugs and radiotherapy induce apoptosis in tumour cells (reviewed in 108,111). This discovery highlights future avenues for therapeutic intervention because these diverse cytotoxic treatments have been shown to stimulate a common cell death program. For example, early studies by Ijiri and Potten (67) demonstrated that 18 commonly used cytotoxic drugs and radiation all induced apoptosis in the proliferative compartment of the small intestinal crypts. In vitro and in vivo studies have shown that the early apoptotic events (within 12 to $24 \mathrm{~h}$ ) observed after administration of cytotoxic drugs or radiation are mediated by DNA damage-induced activation of p53 and, consequently, is completely absent in p53 knockout mice $(68,112)$. However, p53-independent apoptosis may also occur at a later time following cytotoxic insult (82). Consistent with this observation is the fact that, in clinical practice, it has been frequently observed that tumours with mutant p53 are resistant to chemotherapy or radiotherapy. This can now be understood because p53-dependent apoptosis cannot be activated by DNA damage in these tumours $(113,114)$.

COX: There is a wealth of evidence that NSAIDs, which have a principle action of inhibiting COX isoenzymes, COX-1 and COX-2, prevent colorectal cancer (90). The protective effect of NSAIDs may be due to their ability to induce apoptosis, possibly via the inhibition of COX-2 (115). In turn, overexpression of COX-2 increases Bcl-2 expression. Increased apoptosis has been observed in in vivo studies of NSAID-induced colitis (116) and in patients with familial adenomatous polyposis treated with sulindac (117), as well as in in vitro colorectal cell lines following addition of either sulindac or acetylsalicylic acid (118).

Antioxidants: Chemotherapy for disseminated colorectal cancer relies on 5-fluorouracil (5-FU), but its efficacy remains disappointing. Current therapeutic strategies rely on combining 5-FU with other agents that enhance or complement its action (comodulators), such as leucovorin (tetrahydrofolate) and levamisole. Recently, it has been observed that the antioxidants pyrrolidinedithiocarbamate (PDTC) and the water soluble vitamin E analogue 6-hydroxy- 2,5,7,8-tetramethylachroman-carboxylic acid enhance 5-FUinduced apoptosis in cultured colorectal cancer cells regardless of their p53 status $(119,120)$. PDTC-induced apoptosis may be mediated via the CCAAT enhancer-binding protein-beta and involve the activation of the cyclin-dependent kinase inhibitor $\mathrm{p} 21^{\mathrm{WAF} / \mathrm{CIP} 1}$. Other new agents that induce apoptosis in transformed cells and that have potential as new anticancer drugs include betulinic acid, paclitaxel (Taxol, Bristol Myers Squibb, Canada) and retinoids (111).

\section{CONCLUSIONS}

There are four major messages from this review. First, studies with the small nematode $C$ elegans have identified a number of apoptosis-regulating genes - evidence that programmed cell death is an active process under genetic control. Many of these genes have mammalian homologues that seem to regulate mammalian apoptosis. These studies have also led to the identification of the signal transduction pathways of apoptosis and the identification of the caspases. Much remains to be learned in this field. Second, the intestinal crypt is a highly topologically organized system, in which changes can be quantified. These studies have shown that there are fundamental differences in position and function of stem cells, apoptotic processes and regulatory genes in the small intestine versus the large intestine. These differences may explain differences in cancer incidences between these sites. Third, it has become clear that carcinogenesis (and the colorectum is one good example) is characterized by dysregulation of apoptotic programs. Finally, there is an increasing focus on potential manipulation of apoptotic processes, with the hope of being able to interfere with apoptosis regulation and develop new therapeutic concepts.

ACKNOWLEDGEMENTS: Professor Christopher Potten is supported by the Cancer Research Campaign. Mr Andrew Renehan and Mr Simon Bach are in part supported by the Christie Hospital Surgical Endowment Fund. We acknowledge Dr Mark Pritchard for conceptualizing Figure 1. We also thank Dr James Wilson for his critical appraisal of this manuscript.

\section{REFERENCES}

1. Wyllie AH, Kerr JF, Currie AR. Cell death: the significance of apoptosis. Int Rev Cytol 1980;68:251-306.

2. Kerr JF, Wyllie AH, Currie AR. Apoptosis: a basic biological phenomenon with wide-ranging implications in tissue kinetics. Br J Cancer 1972;26:239-57.

3. Wyllie AH. Apoptosis and the regulation of cell numbers in normal and neoplastic tissues: an overview. Cancer Metastasis Rev 1992;11:95-103.

4. Thompson CB. Apoptosis in the pathogenesis and treatment of disease. Science 1995;267:1456-62.

5. Peter ME, Heufelder AE, Hengartner MO. Advances in apoptosis research. Proc Natl Acad Sci 1997;94:12736-7.

6. Liebermann DA. Normal development, oncogenesis and programmed cell death. Oncogene 1998;17:1189-94.

7. Evan G, Littlewood T. A matter of life and cell death. Science 1998;281:1317-22. 
8. Green DR, Reed JC. Mitochondria and apoptosis. Science 1998;281:1309-12.

9. Dive C, Hickman JA. Drug-target interactions: only the first step in the commitment to a programmed cell death? Br J Cancer 1991;64:192-6.

10. Hickman JA, Potten CS, Merritt AJ, Fisher TC. Apoptosis and cancer chemotherapy. Philos Trans R Soc Lond B Biol Sci 1994;345:319-25.

11. Pritchard DM, Watson AJ. Apoptosis and gastrointestinal pharmacology. Pharmacol Ther 1996;72:149-69.

12. Glucksmann A. Cell death in vertebrate ontogeny. Biol Rev 1951;26:59-86.

13. Lockskin RA, Williams CM. Programmed cell death: cytology of degeneration in the intersegmental muscles of the silkmoth. J Insect Physiol 1965;11:123-33.

14. Arends MJ, Wyllie AH. Apoptosis: mechanisms and roles in pathology. Int Rev Exp Pathol 1991;32:223-54.

15. Gavrieli Y, Sherman Y, Ben-Sasson SA. Identification of programmed cell death in situ via specific labeling of nuclear DNA fragmentation. J Cell Biol 1992;119:493-501.

16. Ansari B, Coates PJ, Greenstein BD, Hall PA. In situ end-labelling detects DNA strand breaks in apoptosis and other physiological and pathological states. J Pathol 1993;170:1-8.

17. Brunet CL, Gunby RH, Benson RS, Hickman JA, Watson AJ, Brady G. Commitment to cell death measured by loss of clonogenicity is separable from the appearance of apoptotic markers. Cell Death Differ 1998;5:107-15.

18. Potten CS. What is an apoptotic index measuring? A commentary. Br J Cancer 1996;74:1743-8.

19. Hall PA. Assessing apoptosis: a critical survey. Endocr Relat Cancer 1999;6:3-8.

20. Hall PA, Coates PJ. Assessment of cell proliferation in pathology what next? Histopathology 1995;26:105-12.

21. Dragovich T, Rudin CM, Thompson CB. Signal transduction pathways that regulate cell survival and cell death. Oncogene 1998;17:3207-13.

22. Basu S, Kolesnick R. Stress signals for apoptosis: ceramide and c-Jun kinase. Oncogene 1998;17:3277-85.

23. Alnemri ES, Livingston DJ, Nicholson DW, et al. Human ICE/CED-3 protease nomenclature. Cell 1996;87:171.

24. Nunez G, Benedict MA, Hu Y, Inohara N. Caspases: the proteases of the apoptotic pathway. Oncogene 1998;17:3237-45.

25. Soengas MS, Alarcon RM, Yoshida H, et al. Apaf-1 and caspase-9 in p53-dependent apoptosis and tumor inhibition. Science 1999;284:156-9.

26. Cory S, Vaux DL, Strasser A, Harris AW, Adams JM. Insights from Bcl-2 and Myc: malignancy involves abrogation of apoptosis as well as sustained proliferation. Cancer Res 1999;59(Suppl):1685S-92S.

27. Enari M, Sakahira H, Yokoyama H, Okawa K, Iwamatsu A, Nagata S. A caspase-activated DNase that degrades DNA during apoptosis, and its inhibitor ICAD. Nature 1998;391:43-50.

28. Sugimot A, Miura M. Death signalling in C. elegans and activation mechanisms of caspases. In: Wilson JW, Booth C, Potten CS, eds. Apoptosis Genes. Boston: Kluwer Academic Publishers, 1998:167-204.

29. Horvitz HR. Genetic control of programmed cell death in the nematode Caenorhabditis elegans. Cancer Res 1999;59(Suppl):1701S-6S.

30. Sulston JE, Horvitz HR. Post-embryonic cell lineages of the nematode, Caenorhabditis elegans. Dev Biol 1977;56:110-56.

31. Hengartner MO, Horvitz HR. The ins and outs of programmed cell death during C. elegans development. Philos Trans R Soc Lond B Biol Sci 1994;345:243-6.

32. Cerretti DP, Kozlosky CJ, Mosley B, et al. Molecular cloning of the interleukin-1 beta converting enzyme. Science 1992;256:97-100.

33. Thornberry NA, Bull HG, Calaycay JR, et al. A novel heterodimeric cysteine protease is required for interleukin-1 beta processing in monocytes. Nature 1992;356:768-74.

34. Zou H, Henzel WJ, Liu X, Lutschg A, Wang X. Apaf-1, a human protein homologous to C. elegans CED-4, participates in cytochrome c-dependent activation of caspase-3. Cell 1997;90:405-13.

35. Tsujimoto Y, Cossman J, Jaffe E, Croce CM. Involvement of the bcl-2 gene in human follicular lymphoma. Science 1985;228:1440-3.

36. Hockenbery D, Nunez G, Milliman C, Schreiber RD, Korsmeyer SJ. $\mathrm{Bcl}-2$ is an inner mitochondrial membrane protein that blocks programmed cell death. Nature 1990;348:334-6.
37. Reed JC. Bcl-2 and the regulation of programmed cell death. J Cell Biol 1994;124:1-6.

38. Korsmeyer SJ. BCL-2 gene family and the regulation of programmed cell death. Cancer Res 1999;59(Suppl):1693S-700S.

39. Krajewski S, Tanaka S, Takayama S, Schibler MJ, Fenton W, Reed JC. Investigation of the subcellular distribution of the bcl-2 oncoprotein: residence in the nuclear envelope, endoplasmic reticulum, and outer mitochondrial membranes. Cancer Res 1993;53:4701-14.

40. Kroemer G, Petit P, Zamzami N, Vayssiere JL, Mignotte B. The biochemistry of programmed cell death. FASEB J 1995;9:1277-87.

41. Kelekar A, Thompson CB. Bcl-2-family proteins: the role of the $\mathrm{BH} 3$ domain in apoptosis. Trends Cell Biol 1998;8:324-30.

42. Boise LH, Gonzalez Garcia M, Postema CE, et al. Bcl-x, a bcl-2related gene that functions as a dominant regulator of apoptotic cell death. Cell 1993;74:597-608.

43. Krajewski S, Krajewska M, Shabaik A, et al. Immunohistochemical analysis of in vivo patterns of Bcl-X expression. Cancer Res 1994;54:5501-7.

44. Oltvai ZN, Milliman CL, Korsmeyer SJ. Bcl-2 heterodimerizes in vivo with a conserved homolog, Bax, that accelerates programmed cell death. Cell 1993;74:609-19.

45. Yang E, Zha J, Jockel J, Boise LH, Thompson CB, Korsmeyer SJ. $\mathrm{Bad}$, a heterodimeric partner for Bcl-XL and Bcl-2, displaces Bax and promotes cell death. Cell 1995;80:285-91.

46. Farrow SN, White JH, Martinou I, et al. Cloning of a bcl-2 homologue by interaction with adenovirus E1B 19K. Nature 1995;374:731-3.

47. Lane DP, Crawford LV. T antigen is bound to a host protein in SV40. transformed cells. Nature 1979;278:261-3.

48. Linzer DI, Levine AJ. Characterization of a $54 \mathrm{~K}$ dalton cellular SV40 tumor antigen present in SV40-transformed cells and uninfected embryonal carcinoma cells. Cell 1979;17:43-52.

49. Hollstein M, Sidransky D, Vogelstein B, Harris CC. p53 mutations in human cancers. Science 1991;253:49-53.

50. Carson DA, Lois A. Cancer progression and p53. Lancet 1995;346:1009-11.

51. Steele RJ, Thompson AM, Hall PA, Lane DP. The p53 tumour suppressor gene. Br J Surg 1998;85:1460-7.

52. Murphy M, Levine AJ. The role of p53 in apoptosis. In: Wilson JW, Booth C, Potten CS, eds. Apoptosis Genes. Boston: Kluwer Academic Publishers, 1998:5-36.

53. Lane DP. Cancer. p53, guardian of the genome. Nature 1992;358:15-6.

54. Norimura T, Nomoto S, Katsuki M, Gondo Y, Kondo S. p53-dependent apoptosis suppresses radiation-induced teratogenesis. Nat Med 1996;2:577-80.

55. Nomoto S, Ootsuyama A, Shioyama Y, Katsuki M, Kondo S, Norimura T. The high susceptibility of heterozygous $\mathrm{p} 53(+/-)$ mice to malformation after foetal irradiation is related to sub-competent apoptosis. Int J Radiat Biol 1998;74:419-29.

56. Miyashita T, Krajewski S, Krajewska M, et al. Tumor suppressor p53 is a regulator of bcl-2 and bax gene expression in vitro and in vivo. Oncogene 1994;9:1799-805.

57. Polyak K, Xia Y, Zweier JL, Kinzler KW, Vogelstein B. A model for p53-induced apoptosis. Nature 1997;389:300-5.

58. Wilson JW, Pritchard DM, Hickman JA, Potten CS. Radiationinduced p53 and p21WAF-1/CIP1 expression in the murine intestinal epithelium: apoptosis and cell cycle arrest. Am J Pathol 1998;153:899-909.

59. Kaelin WG Jr. The emerging p53 gene family. J Natl Cancer Inst 1999;91:594-8.

60. Chin YE, Fu X-Y. Control of apoptosis through gene regulation. In: Wilson JW, Booth C, Potten CS, eds. Apoptosis Genes. Boston: Kluwer Academic Publishers, 1998:119-42.

61. Potten CS. Structure, function and proliferative organisation of mammalian gut. In: Potten CS, Hendry JH, eds. Radiation and Gut. Amsterdam: Elsevier Science BV, 1995:1-31.

62. Potten CS. The significance of spontaneous and induced apoptosis in the gastrointestinal tract of mice. Cancer Metastasis Rev 1992;11:179-95.

63. Potten CS, Booth C, Pritchard DM. The intestinal epithelial stem cell: the mucosal governor. Int J Exp Pathol 1997;78:219-43. 
64. Potten CS, Wilson JW, Booth C. Regulation and significance of apoptosis in the stem cells of the gastrointestinal epithelium. Stem Cells 1997;15:82-93.

65. Potten CS. Stem cells in gastrointestinal epithelium: numbers, characteristics and death. Philos Trans R Soc Lond B Biol Sci 1998;353:821-30

66. Cai WB, Roberts SA, Potten CS. The number of clonogenic cells in crypts in three regions of murine large intestine. Int J Radiat Biol 1997;71:573-9.

67. Ijiri K, Potten CS. Further studies on the response of intestinal crypt cells of different hierarchical status to eighteen different cytotoxic agents. Br J Cancer 1987;55:113-23.

68. Merritt AJ, Potten CS, Kemp CJ, et al. The role of p53 in spontaneous and radiation-induced apoptosis in the gastrointestinal tract of normal and p53-deficient mice. Cancer Res 1994;54:614-7.

69. Moss SF, Agarwal B, Arber N, et al. Increased intestinal Bak expression results in apoptosis. Biochem Biophys Res Commun 1996;223:199-203

70. Chang WC, Chapkin RS, Lupton JR. Predictive value of proliferation, differentiation and apoptosis as intermediate markers for colon tumorigenesis. Carcinogenesis 1997;18:721-30.

71. Hall PA, Coates PJ, Ansari B, Hopwood D. Regulation of cell number in the mammalian gastrointestinal tract: the importance of apoptosis. J Cell Sci 1994;107:3569-77.

72. Sterle M, Pipan N. Analysis of the cell death in the mucoid epithelium of mouse stomach. Folia Histochem Cytobiol 1994:32:155-60.

73. Parsonnet J, Friedman GD, Vandersteen DP, et al. Helicobacter pylori infection and the risk of gastric carcinoma. $\mathrm{N}$ Engl J Med 1991;325:1127-31.

74. Wagner S, Beil W, Westermann J, et al. Regulation of gastric epithelial cell growth by Helicobacter pylori: Evidence for a major role of apoptosis. Gastroenterology 1997;113:1836-47.

75. Rudi J, Kuck D, Strand S, et al. Involvement of the CD95 (APO-1/Fas) receptor and ligand system in Helicobacter pyloriinduced gastric epithelial apoptosis. J Clin Invest 1998;102:1506-14.

76. Merritt AJ, Potten CS, Watson AJ, et al. Differential expression of bcl-2 in intestinal epithelia. Correlation with attenuation of apoptosis in colonic crypts and the incidence of colonic neoplasia. J Cell Sci 1995;108:2261-71.

77. Krajewski S, Krajewska M, Shabaik A, Miyashita T, Wang HG, Reed JC. Immunohistochemical determination of in vivo distribution of Bax, a dominant inhibitor of Bcl-2. Am J Pathol $1994 ; 145: 1323-36$

78. Krajewski S, Bodrug S, Krajewska M, et al. Immunohistochemical analysis of Mcl-1 protein in human tissues. Differential regulation of $\mathrm{Mcl}-1$ and $\mathrm{Bcl}-2$ protein production suggests a unique role for Mcl-1 in control of programmed cell death in vivo. Am J Pathol 1995;146:1309-19.

79. Krajewski S, Krajewska M, Reed JC. Immunohistochemical analysis of in vivo patterns of Bak expression, a proapoptotic member of the Bcl-2 protein family. Cancer Res 1996;56:2849-55.

80. Kitada S, Krajewska M, Zhang X, et al. Expression and location of pro-apoptotic $\mathrm{Bcl}-2$ family protein BAD in normal human tissues and tumor cell lines. Am J Pathol 1998;152:51-61.

81. Wilson JW, Potten CS. Immunohistochemical localization of BAX and BAD in normal and BCL-2 null gastrointestinal tract. Apoptosis 1996;1:183-90.

82. Merritt AJ, Allen TD, Potten CS, Hickman JA. Apoptosis in small intestinal epithelial from $\mathrm{p} 53$-null mice: evidence for a delayed, p53-independent G2/M-associated cell death after gammairradiation. Oncogene 1997;14:2759-66.

83. Potten CS. Regulation and significance of apoptosis in stem cells of the gastrointestinal epithelium. In: Andus T, Rogler G, Schlottmann K, et al. Cytokines and Cell Homeostasis in the Gastrointestinal Tract. Proceedings of the Falk Regensburg Conference. Boston: Kluwer Publishing, 1999:82-90.

84. Pan H, Yin C, Van Dyke T. Apoptosis and cancer mechanisms. Cancer Surv 1997;29:305-27.

85. McDonnell TJ, Korsmeyer SJ. Progression from lymphoid hyperplasia to high-grade malignant lymphoma in mice transgenic for the $\mathrm{t}(14 ; 18)$. Nature 1991;349:254-6.

86. Symonds H, Krall L, Remington L, et al. p53-dependent apoptosis suppresses tumor growth and progression in vivo. Cell 1994;78:703-11.
87. Saenz Robles MT, Symonds H, Chen J, Van Dyke T. Induction versus progression of brain tumor development: differential functions for the pRB- and p53-targeting domains of simian virus 40 T antigen. Mol Cell Biol 1994;14:2686-98.

88. Symonds H, Krall L, Remington L, Saenz Robles M, Jacks T, Van Dyke T. p53-dependent apoptosis in vivo: impact of p53 inactivation on tumorigenesis. Cold Spring Harb Symp Quant Biol 1994;59:247-57.

89. Bedi A, Pasricha PJ, Akhtar AJ, et al. Inhibition of apoptosis during development of colorectal cancer. Cancer Res 1995;55:1811-6.

90. Sinicrope FA, Roddey G, McDonnell TJ, Shen Y, Cleary KR, Stephens LC. Increased apoptosis accompanies neoplastic development in the human colorectum. Clin Cancer Res 1996;2:1999-2006.

91. Gupta RA, DuBois RN. Aspirin, NSAIDS, and colon cancer prevention: mechanisms? Gastroenterology 1998;114:1095-8.

92. O'Connell J, Bennett MW, O'Sullivan G, Collins JK, Shanahan F. Fas counter-attack - the best form of tumor defense? Nat Med 1999;5:267-8.

93. O'Connell J, O'Sullivan G, Collins JK, Shanahan F. The Fas counterattack: Fas-mediated T cell killing by colon cancer cells expressing Fas ligand. J Exp Med 1996;184:1075-82.

94. O'Connell J, Bennett MW, O'Sullivan G, et al. Fas ligand expression in primary colon adenocarcinomas: evidence that the Fas counterattack is a prevalent mechanism of immune evasion in human colon cancer. J Pathol 1998;186:240-6.

95. Fisher CJ, Gillett CE, Vojtesek B, Barnes DM, Millis RR. Problems with p53 immunohistochemical staining: the effect of fixation and variation in the methods of evaluation. Br J Cancer 1994;69:26-31.

96. Baker SJ, Markowitz S, Fearon ER, Willson JK, Vogelstein B. Suppression of human colorectal carcinoma cell growth by wild-type p53. Science 1990;249:912-5.

97. Purdie CA, O'Grady J, Piris J, Wyllie AH, Bird CC. p53 expression in colorectal tumors. Am J Pathol 1991;138:807-13.

98. Manne U, Myers RB, Moron C, et al. Prognostic significance of $\mathrm{Bcl}-2$ expression and $\mathrm{p} 53$ nuclear accumulation in colorectal adenocarcinoma. Int J Cancer 1997;74:346-58.

99. Donehower LA, Harvey M, Slagle BL, et al. Mice deficient for p53 are developmentally normal but susceptible to spontaneous tumours. Nature 1992;356:215-21

100. Clarke AR, Cummings MC, Harrison DJ. Interaction between murine germline mutations in $\mathrm{p} 53$ and APC predisposes to pancreatic neoplasia but not to increased intestinal malignancy. Oncogene 1995;11:1913-20.

101. Hague A, Moorghen M, Hicks D, Chapman M, Paraskeva C. BCL-2 expression in human colorectal adenomas and carcinomas. Oncogene 1994;9:3367-70.

102. Sinicrope FA, Ruan SB, Cleary KR, Stephens LC, Lee JJ, Levin B. bcl-2 and p53 oncoprotein expression during colorectal tumorigenesis. Cancer Res 1995;55:237-41.

103. Bronner MP, Culin C, Reed JC, Furth EE. The bcl-2 proto-oncogene and the gastrointestinal epithelial tumor progression model. Am J Pathol 1995;146:20-6.

104. Watson AJ, Merritt AJ, Jones LS, et al. Evidence of reciprocity of $\mathrm{bcl}-2$ and $\mathrm{p} 53$ expression in human colorectal adenomas and carcinomas. Br J Cancer 1996;73:889-95.

105. Sinicrope FA, Hart J, Michelassi F, Lee JJ. Prognostic value of bcl-2 oncoprotein expression in stage II colon carcinoma. Clin Cancer Res 1995;1:1103-10.

106. Silvestrini R, Veneroni S, Daidone MG, et al. The Bcl-2 protein: a prognostic indicator strongly related to $\mathrm{p} 53$ protein in lymph nodenegative breast cancer patients. J Natl Cancer Inst 1994;86:499-504

107. Pezzella F, Turley H, Kuzu I, et al. bcl-2 protein in non-small-cell lung carcinoma. N Engl J Med 1993;329:690-4.

108. Reed JC. Regulation of apoptosis by bcl-2 family proteins and its role in cancer and chemoresistance. Curr Opin Oncol 1995;7:541-6.

109. Krajewska M, Moss SF, Krajewski S, Song K, Holt PR, Reed JC. Elevated expression of Bcl-X and reduced Bak in primary colorectal adenocarcinomas. Cancer Res 1996;56:2422-7.

110. Wilson JW, Nostro MC, Balzi M, et al. Bcl-w expression in colorectal adenocarcinoma. Br J Cancer 2000;82:178-85.

111. Watson AJ, Lowenstein P. Therapeutic manipulation of apoptosis in cancer and neurological disease. In: Wilson JW, Booth C, Potten CS, eds. Apoptosis Genes. Boston: Kluwer Academic Publishers, 1998:281-303. 
112. Pritchard DM, Potten CS, Hickman JA. The relationships between p53-dependent apoptosis, inhibition of proliferation, and 5-fluorouracil-induced histopathology in murine intestinal epithelia. Cancer Res 1998;58:5453-65.

113. Berns EM, van Staveren IL, Look MP, Smid M, Klijn JG, Foekens JA. Mutations in residues of TP53 that directly contact DNA predict poor outcome in human primary breast cancer. Br J Cancer 1998;77:1130-6.

114. Lens D, Dyer MJ, Garcia Marco JM, et al. p53 abnormalities in Cll are associated with excess of prolymphocytes and poor prognosis. Br J Haematol 1997;99:848-57.

115. Watson AJ, Dubois RN. Lipid metabolism and APC: implications for colorectal cancer prevention. Lancet 1997;349:444-5.

116. Lee FD. Importance of apoptosis in the histopathology of drug related lesions in the large intestine. J Clin Pathol 1993;46:118-22.

117. Pasricha PJ, Bedi A, O'Conner K, et al. The effects of sulindac on colorectal proliferation and apoptosis in familial adenomatous polyposis. Gastroenterology 1995;109:994-8.

118. Piazza GA, Rahm AL, Krutzsch M, et al. Antineoplastic drugs sulindac sulfide and sulfone inhibit cell growth by inducing apoptosis. Cancer Res 1995;55:3110-6.

119. Chinery R, Brockman JA, Dransfield DT, Coffey RJ. Antioxidantinduced nuclear translocation of CCAAT/enhancer-binding protein beta. A critical role for protein kinase A-mediated phosphorylation of Ser299. J Biol Chem 1997;272:30356-61.

120. Chinery R, Brockman JA, Peeler MO, Shyr Y, Beauchamp RD, Coffey RJ. Antioxidants enhance the cytotoxicity of chemotherapeutic agents in colorectal cancer: a p53-independent induction of $\mathrm{p} 21^{\mathrm{WAF}}$ /CIP1 via C/EBPbeta. Nat Med 1997;3:1233-41.

121. Fraser A, McCarthy N, Evan GI. Biochemistry of cell death. Curr Opin Neurobiol 1996;6:71-80.

122. Darzynkiewicz Z, Bruno S, Del Bino G, et al. Features of apoptotic cells measured by flow cytometry. Cytometry 1992;13:795-808.
123. Dive C, Gregory CD, Phipps DJ, Evans DL, Milner AE, Wyllie AH. Analysis and discrimination of necrosis and apoptosis (programmed cell death) by multiparameter flow cytometry. Biochim Biophys Acta 1992;1133:275-85.

124. Nicoletti I, Migliorati G, Pagliacci MC, Grignani F, Riccardi C. A rapid and simple method for measuring thymocyte apoptosis by propidium iodide staining and flow cytometry. J Immunol Methods 1991;139:271-9.

125. Martin SJ, Reutelingsperger CP, McGahon AJ, et al. Early redistribution of plasma membrane phosphatidylserine is a general feature of apoptosis regardless of the initiating stimulus: inhibition by overexpression of Bcl-2 and Abl. J Exp Med 1995;182:1545-56.

126. Garden GA, Bothwell M, Rubel EW. Lack of correspondence between mRNA expression for a putative cell death molecule (SGP-2) and neuronal cell death in the central nervous system. J Neurobiol 1991;22:590-604.

127. Hilton DA, Love S, Barber R. Demonstration of apoptotic cells in tissue sections by in situ hybridization using digoxigenin-labeled poly(A) oligonucleotide probes to detect thymidine-rich DNA sequences. J Histochem Cytochem 1997;45:13-20.

128. Gibson L, Holmgreen SP, Huang DC, et al. bcl-w, a novel member of the bcl-2 family, promotes cell survival. Oncogene 1996;13:665-75.

129. Ambrosini G, Adida C, Altieri DC. A novel anti-apoptosis gene, survivin, expressed in cancer and lymphoma. Nat Med 1997;3:917-21.

130. Willis TG, Jadayel DM, Du MQ, et al. Bcl10 is involved in $\mathrm{t}(1 ; 14)(\mathrm{p} 22 ; \mathrm{q} 32)$ of MALT B cell lymphoma and mutated in multiple tumor types. Cell 1999;96:35-45.

131. Hoffman B, Liebermann DA. The proto-oncogene c-myc and apoptosis. Oncogene 1998;17:3351-7.

132. Takayama S, Sato T, Krajewski S, et al. Cloning and functional analysis of BAG-1: a novel Bcl-2-binding protein with anti-cell death activity. Cell 1995;80:279-84. 


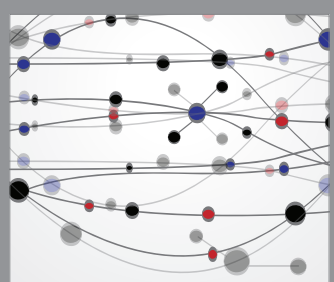

The Scientific World Journal
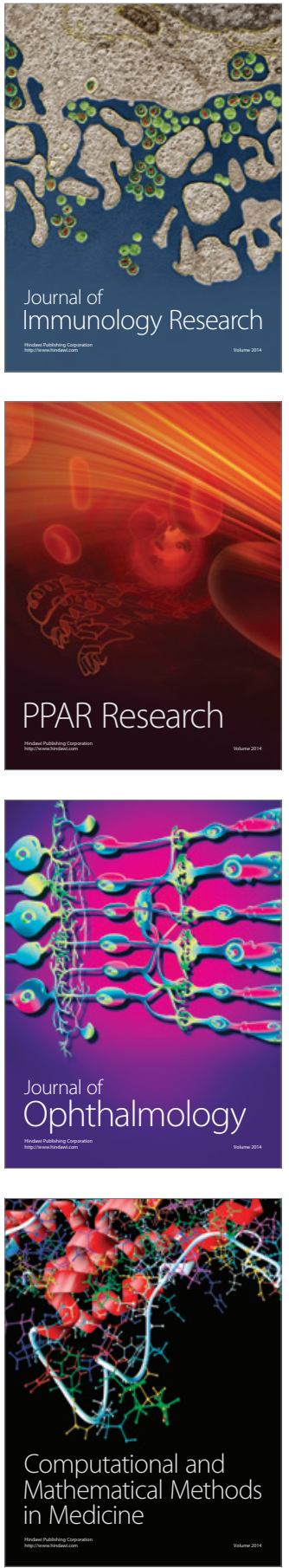

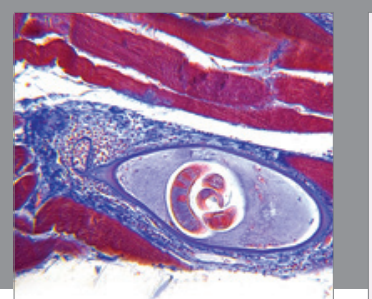

Gastroenterology Research and Practice

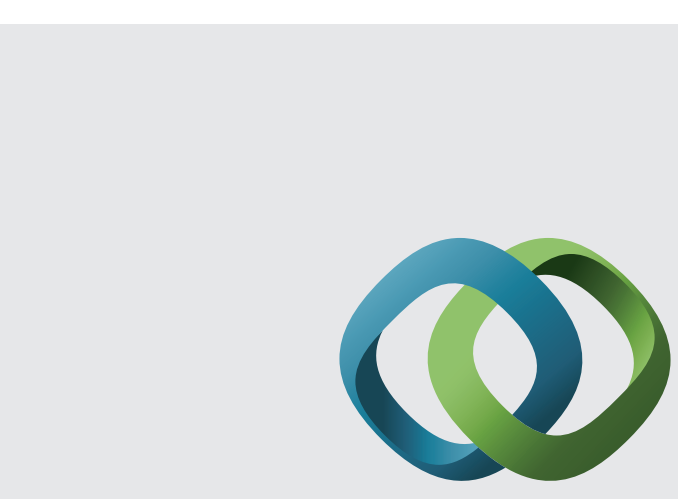

\section{Hindawi}

Submit your manuscripts at

http://www.hindawi.com
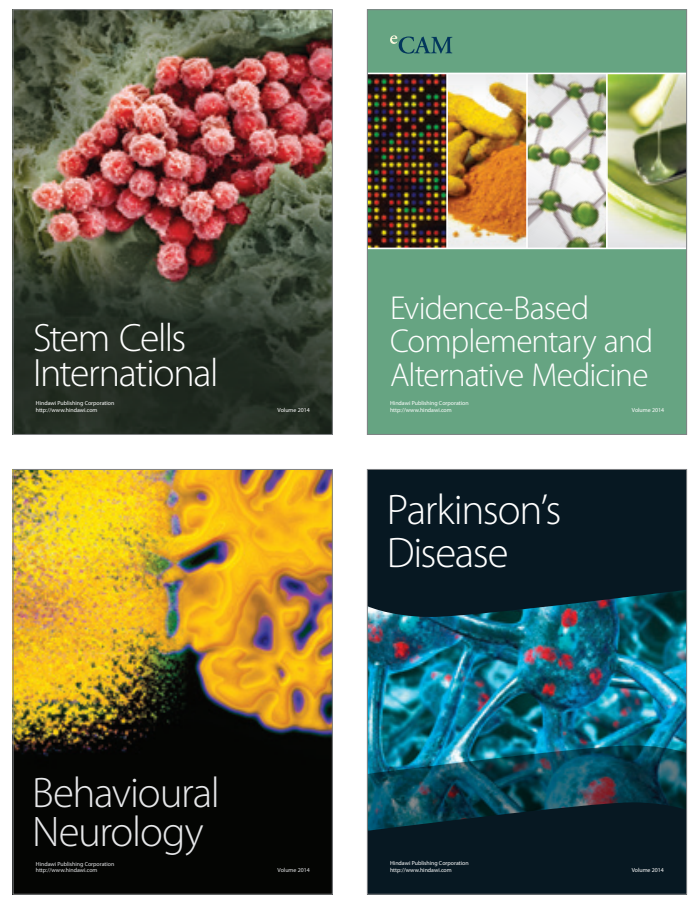
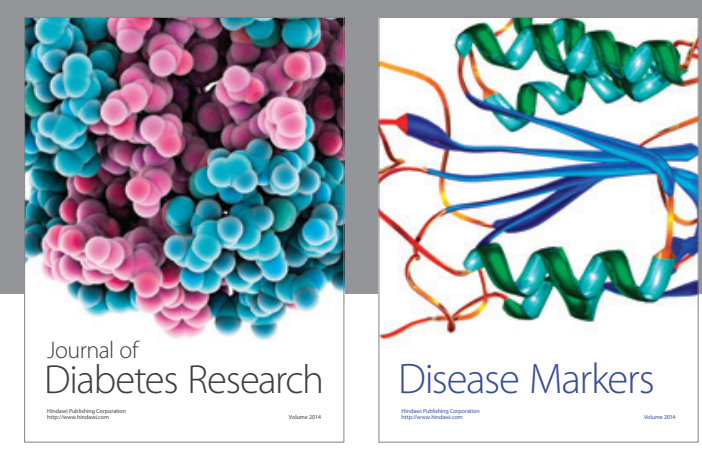

Disease Markers
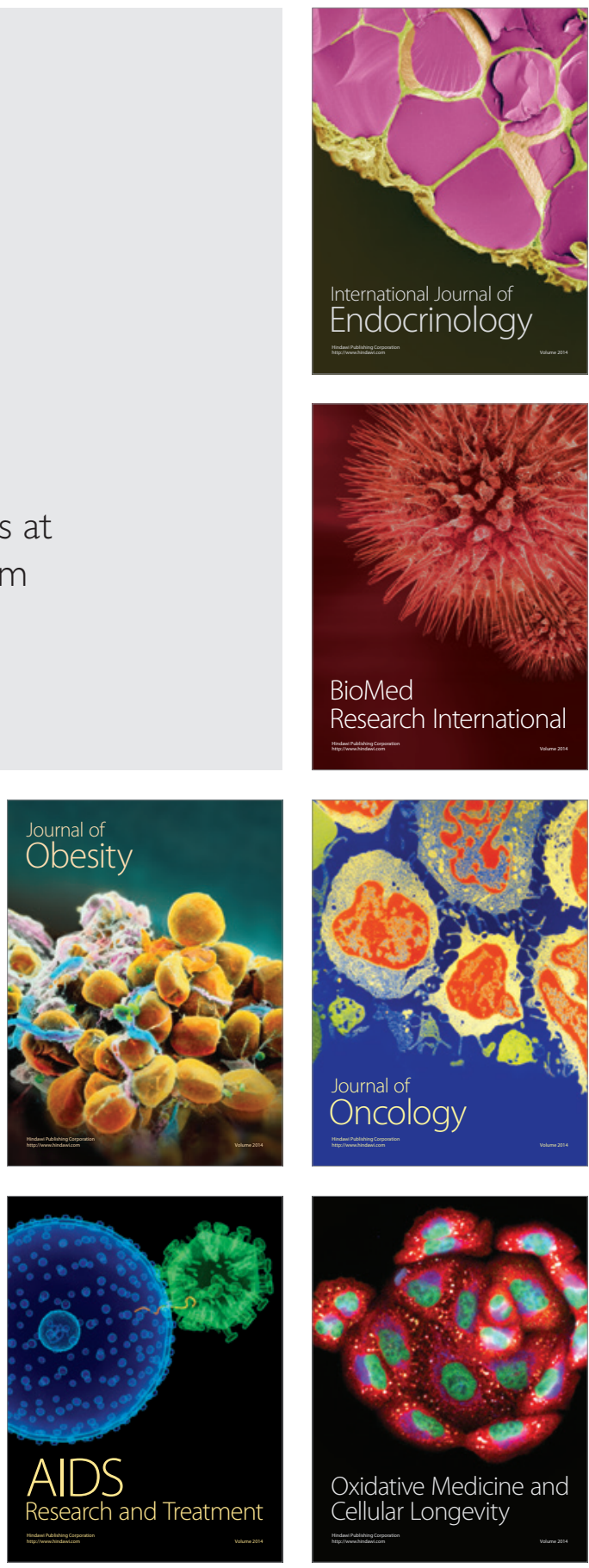